\title{
Oxalate decarboxylase of the white-rot fungus Dichomitus squalens demonstrates a novel enzyme primary structure and non-induced expression on wood and in liquid cultures
}

\author{
Miia R. Mäkelä, Kristiina Hildén, Annele Hatakka and Taina K. Lundell \\ Department of Applied Chemistry and Microbiology, Division of Microbiology, Viikki Biocenter, \\ PO Box 56, FIN-00014 University of Helsinki, Finland
}

Correspondence

Miia R. Mäkelä

miia.r.makela@helsinki.fi

Received 3 March 2009

Revised 20 April 2009

Accepted 21 April 2009

\section{INTRODUCTION}

Oxalic acid is the predominant organic acid produced by wood-rotting fungi when they are cultivated on defined liquid media or on solid lignocelluloses (Kuan \& Tien, 1993; Shimada et al., 1997; Galkin et al., 1998; Urzúa et al., 1998; Hofrichter et al., 1999; Mäkelä et al., 2002). According to the type of decay that they cause on wood, these organisms may be classified as white-, brown- and soft-rot fungi (Kuan \& Tien, 1993; Hatakka, 2001).

Fungi synthesize oxalic acid in their mitochondria as a waste compound from the tricarboxylic acid cycle, and by the glyoxylate cycle that operates in the glyoxysomes (Espejo \& Agosin, 1991; Dutton \& Evans, 1996; Munir et al., 2001). Typically, brown-rot fungi produce high quantities of extracellular oxalic acid (Dutton et al., 1993;

Abbreviations: FDH, formate dehydrogenase; FPLC, fast protein liquid chromatography; GAPDH, glyceraldehyde-3-phosphate dehydrogenase; ODC, oxalate decarboxylase; OXC, oxalyl-CoA decarboxylase; OXO, oxalate oxidase; qRT-PCR, quantitative RT-PCR; UTR, untranscribed region.

The GenBank/EMBL/DDBJ accession numbers for the sequences determined in this work are FM946037, FM955140, FM946036, and FM954981 for odc, cDNA of odc, partial gapdh of $D$. squalens FBCC312, and odc of D. squalens FBCC184, respectively.
Espejo \& Agosin, 1991), although it has been shown that both white- and brown-rot fungi express specific oxalatedegrading enzymes (Mehta \& Datta, 1991; Dutton et al., 1994; Micales, 1997; Aguilar et al., 1999; Mäkelä et al., 2002).

Three types of oxalate-degrading enzymes have been described in microbes and plants: oxalate decarboxylases (ODC, EC 4.1.1.2), oxalate oxidases (OXO, EC 1.2.3.4) and oxalyl-CoA decarboxylases (OXC, EC 4.1.1.8) (Svedružić et al., 2005). ODC, isolated from fungi and bacteria, is a Mn-containing enzyme that decomposes oxalic acid to formic acid and $\mathrm{CO}_{2}$ in a reaction that requires $\mathrm{O}_{2}$ (Reinhardt et al., 2003). ODCs belong to the cupin protein superfamily, characterized by a conserved metal-ionbinding cupin motif with an overall $\beta$-barrel fold (Dunwell et al., 2000, 2004), and are further classified as bicupins, as ODCs possess two cupin motifs, probably due to an evolutionary gene duplication event (Dunwell et al., 2004). The evolutionarily related monocupin enzyme OXO similarly requires $\mathrm{O}_{2}$ but cleaves oxalic acid to two $\mathrm{CO}_{2}$ with generation of $\mathrm{H}_{2} \mathrm{O}_{2}$. OXO is expressed mainly in plants; only one fungal OXO has been reported so far (Aguilar et al., 1999). The third enzyme, OXC, is a bacterial enzyme, which converts activated oxalyl-CoA to formyl- 
$\mathrm{CoA}$ and $\mathrm{CO}_{2}$, and is linked to oxalate-dependent synthesis of ATP, at least in Oxalobacter formigenes (Anantharam et al., 1989).

The best-characterized ODC enzyme is from Bacillus subtilis, with the crystallized protein structure available (Emiliani \& Bekes, 1964; Anand et al., 2002). ODCs from several species of basidiomycetous and ascomycetous fungi have been reported (Emiliani \& Bekes, 1964; Magro et al., 1988; Mehta \& Datta, 1991; Dutton et al., 1994; Micales, 1997; Kathiara et al., 2000; Mäkelä et al., 2002), but so far only one basidiomycetous ODC enzyme, from the whiterot fungus Flammulina (Collybia) velutipes has been thoroughly characterized, at both the gene and protein level (Mehta \& Datta, 1991; Kesarwani et al., 2000).

Fungal ODCs are considered mainly as intracellular enzymes since only small amounts of extracellular ODC activities have been detected, secreted either to the culture medium or to the fungal cell wall and extracellular polysaccharide layer (Dutton et al., 1994; Kathiara et al., 2000). It is assumed that the major role of ODC in fungi is to prevent too high intracellular levels of oxalic acid, and thereby to control excess secretion of oxalic acid (Micales, 1997; Mäkelä et al., 2002). Secondly, it has been suggested that ODC decomposes extracellular oxalic acid to keep steady levels of $\mathrm{pH}$ and oxalate anions outside the fungal hyphae, as supplementation of oxalic acid or a change to more acidic environmental $\mathrm{pH}$ levels often promotes ODC activities (Mehta \& Datta, 1991; Dutton et al., 1994; Micales, 1997; Mäkelä et al., 2002).

ODC enzymes have several potential and established biotechnological applications. In the pulp and paper industry, oxalate salt deposits have been prevented by enzymic degradation of oxalic acid from the bleaching filtrates of pulping processes (Sjöde et al., 2008). Other applications have utilized ODC in, for example, assays of oxalic acid concentration in clinical and food samples. The construction of transgenic odc-expressing crop plants can (i) improve their resistance against certain oxalic-acidsecreting plant-pathogenic fungi and (ii) by reducing their oxalic acid content, make them less toxic to humans and herbivores (Kesarwani et al., 2000; Dias et al., 2006). In a search for a treatment for excessive excretion of urinary oxalate (hyperoxaluria), oral therapy with a crystalline cross-linked formulation of ODC has been shown to reduce symptoms in experiments with mice (Grujic et al., 2009).

In our previous study, the white-rot basidiomycete Dichomitus squalens (isolate FBCC184, formerly PO114) secreted oxalic acid during growth on wood and demonstrated high levels of mycelial ODC activity after supplementation with excess oxalic acid (Mäkelä et al., 2002). This strain and another isolate of D. squalens (CBS 1000.73) are efficient in decaying spruce wood with selective lignin degradation (Hakala et al., 2004; Fackler et al., 2006). Others have reported that D. squalens (CBS 432.34) expresses multiple laccases and manganese perox- idases (Périé \& Gold, 1991; Périé et al., 1998), employing a typical lignin-modifying enzyme machinery (Hatakka, 2001; Hammel \& Cullen, 2008).

In this work, we cloned and sequenced a novel ODCencoding gene $(D s-o d c)$ and identified the ODC enzyme in mycelial extracts from two distinct wild-type isolates of $D$. squalens. The unique primary structure of Ds-ODC is described; it shows the longest polypeptide main chain (493 aa) for any cloned or isolated ODC enzyme characterized so far. Expression of the Ds-odc gene was studied by real-time quantitative RT-PCR in submerged liquid cultures and during solid-state cultivation on spruce wood sticks. On wood, transcript quantities diminished in the course of cultivation. In the submerged cultures, oxalic acid supplementation caused no increase in transcript amounts. Our results point to a constitutive role of the novel $D s-o d c$ gene, principally operating during primary metabolism.

\section{METHODS}

Fungal cultures. Dichomitus squalens FBCC184 (formerly $D$ squalens PO114) and FBCC312 (formerly D. squalens A-670) from the Fungal Biotechnology Culture Collection, University of Helsinki, Helsinki, Finland (fbcc@helsinki.fi), were maintained on malt agar plates $[2 \%(\mathrm{w} / \mathrm{v})$ malt extract, $2 \%(\mathrm{w} / \mathrm{v})$ agar agar]. Fungi were cultivated in $75 \mathrm{ml} 2 \%(\mathrm{w} / \mathrm{v})$ liquid malt extract medium (submerged cultures) or on $2 \mathrm{~g}$ (dry weight) Norway spruce (Picea abies) wood sticks (solid-state wood cultures) (Mäkelä et al., 2006). The stationary submerged cultures were inoculated with $4 \mathrm{ml}$ mycelial suspension from 7 day cultures as described previously (Mäkelä et al., 2002) and incubated at $28{ }^{\circ} \mathrm{C}$. Oxalic acid (Sigma-Aldrich) was added to the submerged cultures on day 8 to give $2.5 \mathrm{mM}$ or $5 \mathrm{mM}$ final concentration. For extraction of RNA and total protein, the mycelia were harvested after 1 day and 2 days exposure to oxalic acid, respectively.

Protein extraction and chromatofocusing. After treatment with $5 \mathrm{mM}$ oxalic acid, mycelia from submerged cultures of $D$. squalens FBCC184 and FBCC312 were filtered through Miracloth and stored at $-20{ }^{\circ} \mathrm{C}$. For extraction of proteins, the mycelia were ground under liquid $\mathrm{N}_{2}$ with a mortar and pestle and extracted with cold $0.1 \mathrm{M}$ potassium citrate buffer ( $\mathrm{pH} 3.0)$. The suspensions were agitated on a magnetic stirrer for several hours at $4{ }^{\circ} \mathrm{C}$, and centrifuged for $30 \mathrm{~min}$ at $30000 \mathrm{~g}$ at $4{ }^{\circ} \mathrm{C}$. The supernatants were concentrated in an Amicon ultrafiltration unit with a $10 \mathrm{kDa}$ cut-off Omega membrane filter (Filtron) at $4{ }^{\circ} \mathrm{C}$.

The concentrated protein extracts form D. squalens FBCC184 and FBCC312 were dialysed against $40 \mathrm{mM}$ L-histidine buffer ( $\mathrm{pH} 4.5$ ) containing $10 \mathrm{mM} \mathrm{NaCl}$. The protein sample was transferred into a $4 \mathrm{ml}$ MonoP HR 5/20 chromatofocusing column (Pharmacia) using an FPLC (fast protein liquid chromatography) system (Pharmacia). Proteins were eluted with a linear Polybuffer 74 (Amersham Pharmacia Biotech) gradient from 0 to $10 \%$ (from $\mathrm{pH} 4.5$ to 2.3 ) by collecting $1 \mathrm{ml}$ fractions. The $\mathrm{pH}$ and ODC activity of the collected fractions were determined. For measurement of ODC activity, the NADH-generating method described previously was used (Mäkelä et al., 2002). This is a modification of the method of a commercially available kit (Boehringer Mannheim, Cat. No. 755699). The effect of added oxalic acid or acidity in the samples was subtracted by using a sample blank for each measurement (Mäkelä et al., 2002). The fractions showing ODC activity were pooled and concentrated. 
Western blotting. The concentrated protein pools from chromatofocusing of $D$. squalens FBCC184 and FBCC 312 were separated by SDS-PAGE and electroblotted to nitrocellulose membrane. IgG fraction of polyclonal rabbit antiserum against ODC from Aspergillus sp. (Nordic Immunology) was used as the primary antibody. The immunoreacted proteins were detected by alkaline phosphatase conjugated to goat anti-rabbit IgG (Bio-Rad) as the secondary antibody (Hakala et al., 2005; Mäkelä et al., 2006), and visualized with a BCIP/NBT colorimetric assay (Bio-Rad). ODC from Aspergillus sp. (Sigma-Aldrich) was used as positive control. Prestained PageRuler protein size standard (Fermentas) was used for the estimation of protein transfer efficiency and determination of molecular mass.

Extraction of nucleic acids. From the submerged fungal cultures, total DNA and RNA were extracted from ground mycelia frozen under liquid $\mathrm{N}_{2}$ using the methods previously described (Hildén et al., 2005). From the spruce wood cultures, total RNA was extracted by the method described by Chang et al. (1993). Prior to extraction, $2 \mathrm{~g}$ (dry weight) of the fungal-colonized wood sticks was milled in liquid $\mathrm{N}_{2}$ with a Polymix Analysenmühle A10 (Kinematica). DNA was removed by RQ1 RNase-free DNase (Promega). Amount and quality of total RNA was determined by absorbance at $260 \mathrm{~nm}$ and 260 / $280 \mathrm{~nm}$, respectively.

cDNA synthesis. A Smart RACE cDNA Amplification kit (Clontech) was used for the cDNA synthesis. The $20 \mu \mathrm{l}$ reactions, containing $1 \mu \mathrm{g}$ total RNA, $200 \mathrm{U}$ SuperScript III reverse transcriptase (Invitrogen), $4 \mu \mathrm{l} 5 \times$ first strand buffer, $10 \mathrm{mM}$ dithiothreitol, $0.5 \mu \mathrm{M} \mathrm{3}$ '-RACE cDNA synthesis primer, $0.5 \mu \mathrm{M}$ SMART II oligonucleotide and $0.5 \mathrm{mM}$ dNTP mixture (Finnzymes), were carried out according to the instructions of the manufacturer (Clontech).

Amplification of Ds-odc. The genomic $915 \mathrm{bp}$ fragment was amplified from total DNA of D. squalens FBCC312 with odc sense and antisense primers (Table 1) designed according to the cupin 1 and 2 motifs, respectively, of the Flammulina velutipes odc sequence (EMBL accession no. AF200683). The $25 \mu$ PCR mixture contained $0.5 \mu \mathrm{l}$ DNA template, $0.3 \mathrm{mM}$ dNTP mixture (Finnzymes), $0.4 \mu \mathrm{M} 5^{\prime}$ and $3^{\prime}$ primers, $1 \times$ Phusion HF buffer (Finnzymes), $3 \%$ DMSO and $0.8 \mathrm{U}$ Phusion Hot Start DNA polymerase (Finnzymes). PCR was performed with initial denaturation at $98{ }^{\circ} \mathrm{C}$ for $30 \mathrm{~s}$; then 45 cycles of (1) denaturation at $98{ }^{\circ} \mathrm{C}$ for $10 \mathrm{~s}$, (2) annealing at $57{ }^{\circ} \mathrm{C}$ for $30 \mathrm{~s}$,
(3) elongation at $72{ }^{\circ} \mathrm{C}$ for $15 \mathrm{~s}$; and final extension at $72{ }^{\circ} \mathrm{C}$ for $10 \mathrm{~min}$.

The 3' end of the Ds-odc gene was amplified using the Universal Genome Walker kit (Clontech) according to the instructions of the manufacturer. The nested PCR amplification strategy was conducted with a genespecific primer (GSP sense) in the first round of PCR, followed by the second PCR with a nested gene-specific primer (nGSP sense) (Table 1). PCR conditions were as described by Hildén et al. (2005).

The $5^{\prime}$ end of Ds-odc was amplified by the inverse PCR approach. One microgram of total DNA from D. squalens FBCC312 was digested with $1 \mathrm{U}$ EcoRI restriction enzyme (Fermentas). The restricted DNA batch was circularized with $5 \mathrm{U}$ T4 ligase (Fermentas) in a reaction containing $0.5 \mathrm{mM}$ ATP. Circularized DNA templates for inverse PCR were purified with Microcon centrifugal tubes (Millipore). In the first round of PCR amplification, the gene-specific primers (nGSP sense, I-PCR antisense) were used, and in the second PCR round, gene-specific nested primers (nI-PCR sense, nI-PCR antisense) were used (Table 1). PCRs were conducted as described above.

The full-length genomic $o d c$ gene was amplified from the total DNA of both D. squalens isolates (FBCC184 and FBCC312), and the ORF fragment was amplified from the CDNA of D. squalens FBCC312 with primers designed according to the nucleotide sequence data from the genome walking and inverse PCR products (start, end; Table 1). PCR conditions were as described above.

Cloning and sequencing. The PCR amplification products were run on $1 \%$ agarose gels and stained with ethidium bromide. The gels were inspected under UV light and the PCR products of correct size were cut out of the gels, purified with the Geneclean Turbo kit (MP Biomedicals), and cloned into the pJET1.2/blunt vector (Fermentas) according to the instructions of the manufacturers. Double-stranded plasmid DNA was extracted with the GeneJET Plasmid Miniprep kit (Fermentas) and used for sequencing (Magrogen Ltd, Republic of Korea).

Real-time quantitative RT-PCR (qRT-PCR). Real-time qRT-PCR was used to measure relative levels of expression of the Ds-odc gene. The Ds-gapdh gene encoding the glyceraldehyde-3-phosphate dehydrogenase of $D$. squalens was selected as a constantly expressed endogenous control gene to normalize quantification of cDNA in all qRT-PCRs. Gene-specific primer pairs were designed for Ds-odc (odc qPCR sense, odc qPCR antisense) to amplify one intron overlapping,

Table 1. Primers used for cloning and expression studies of the $D$. squalens odc gene

\begin{tabular}{|lll|}
\hline Primer description & \multicolumn{1}{c|}{ Nucleotide sequence $\left(\mathbf{5}^{\prime} \mathbf{- 3}^{\prime}\right)$} & \multicolumn{1}{c|}{ Application } \\
\hline odc sense & GGCGCTATCAGGGAGCTGCA & Genomic PCR \\
GSP antisense & AAAGCACCAGGCTCAACTGT & Genomic PCR \\
nGSP sense & CACAGTCTTCAAGCGACCAA & Genome walking PCR \\
I-PCR antisense & TTCCCGGCTTCGACCCAGAT & Genome walking and inverse PCR \\
nI-PCR sense & AGCAGTCACTTGGACGGAAC & Inverse PCR \\
nI-PCR antisense & GAGACACCGGTAACGACACG & Inverse PCR \\
Start sense & CTCAGCGTTCTTGTGCCAAT & Inverse PCR \\
End antisense & ATGGTCCGCGCACTCCTCTCTCT & Genomic and RT-PCR \\
odc qPCR sense & TCACTGGGACGGGCCTACGA & Genomic and RT-PCR \\
odc qPCR antisense & CTCTTCCCCTCTGGCATTGT & Real-time qRT-PCR \\
gapdh qPCR sense & GCCTACGACGAATTCCTTTG & Real-time qRT-PCR \\
gapdh qPCR antisense & GCTACCGGTGTCTTCACCAC & Real-time qRT-PCR \\
& TTGACACCGCAGACAAACAT & Real-time qRT-PCR \\
\hline
\end{tabular}

${ }^{\star}$ GSP, gene-specific primer; nGSP, nested gene-specific primer; I-PCR, inverse PCR; nI-PCR, nested inverse PCR. 
$147 \mathrm{bp}$ and $263 \mathrm{bp}$ products from cDNA and genomic DNA amplicons, respectively (Table 1). For Ds-gapdh, $129 \mathrm{bp}$ and $178 \mathrm{bp}$ (one intron containing) products were amplified from cDNA and genomic DNA, respectively, using the gene-specific primers (gapdh qPCR sense, gapdh qPCR antisense; Table 1).

For each time point and treatment, two biological replicates, i.e. cDNA templates synthesized from RNA extractions from two separate cultivations, were used for the generation of cDNA template, and three replicate PCRs were conducted with each cDNA template. The amplification efficiencies for Ds-odc and Ds-gapdh were determined to be equal by using five serial dilutions, and fold-differences between the samples were calculated by the $2^{-\Delta \Delta C_{t}}$ method (Livak \& Schmittgen, 2001). The $20 \mu \mathrm{l}$ qRT-PCRs contained $0.3 \mu \mathrm{l}$ of the cDNA template, $0.5 \mu \mathrm{M} 5^{\prime}$ and $3^{\prime}$ primers and $1 \times$ Maxima SYBR Green qPCR Master Mix (Fermentas). The qRT-PCRs were performed in an ABI 7300 instrument (Applied Biosystems) using the following cycling parameters: initial denaturation at $95{ }^{\circ} \mathrm{C}$ for $15 \mathrm{~min}$; then 40 cycles of (1) denaturation at $94{ }^{\circ} \mathrm{C}$ for $60 \mathrm{~s}$, (2) annealing at $58{ }^{\circ} \mathrm{C}$ for $30 \mathrm{~s}$, and (3) elongation at $72{ }^{\circ} \mathrm{C}$ for $30 \mathrm{~s}$; and for melting curve analysis, initial denaturation was performed at $95{ }^{\circ} \mathrm{C}$ for $15 \mathrm{~s}$, hybridization at $60{ }^{\circ} \mathrm{C}$ for $30 \mathrm{~s}$, and final denaturation at $95{ }^{\circ} \mathrm{C}$ for $15 \mathrm{~s}$. Fluorescence was measured during the elongation step of qRT-PCR.

Phylogenetic sequence analysis. Translated amino acid ORF sequences of the Ds-odc cDNA clone from isolate FBCC312 and of the full-length genomic DNA clone from isolate FBCC184 were identified and compared to other ODC and OXO sequences with BLAST (http:// www.ncbi.nih.gov/blast) using the BLASTP search algorithm. Nucleotide and Uniprot translated sequences of ODC and OXOencoding genes at EBI-EMBL were retrieved with SRS (http:// www.ebi.ac.uk) and the annotated odc sequences from the whole genome websites of Phanerochaete chrysosporium (http://genome.jgipsf.org/Phchr1/Phchr1.home.html) and Postia placenta (http://genome.jgi-psf.org/Pospl1/Pospl1.home.html). With P. placenta, one allelic sequence variant of each three putative odc gene was used (Martinez et al., 2009). Maximum-parsimony and minimumevolution neighbour-joining trees with a bootstrapping value of 1000 were created for 31 amino acid sequences with the MEGA 4.0 software (http://www.megasoftware.net/) (Tamura et al., 2007).

\section{RESULTS}

\section{ODC activity and pH in submerged cultures}

In the submerged cultures of D. squalens FBCC184 incubated without additional oxalic acid, most of the ODC activity was found in the mycelial fraction (Fig. 1a). ODC activity was hardly detectable in the culture fluids $\left[0.4 \mu \mathrm{mol}\right.$ oxalic acid decarboxylated $(\mathrm{mg} \text { protein })^{-1}$ $\mathrm{min}^{-1}$ ], corresponding to only $2.5 \%$ of the total activity. Addition of $5 \mathrm{mM}$ oxalic acid promoted the highest ODC activity levels, and extracellular ODC activity was increased $\left[9.3 \mu \mathrm{mol}\right.$ oxalic acid decarboxylated $(\mathrm{mg} \text { protein })^{-1}$ $\left.\min ^{-1}\right]$. However, up to $87 \%$ of the ODC activity was in the mycelial extracts $[62 \mu \mathrm{mol}$ oxalic acid decarboxylated $(\mathrm{mg} \text { protein })^{-1} \mathrm{~min}^{-1}$, a 30 -fold increase in comparison to non-induced conditions]. With $10 \mathrm{mM}$ oxalic acid, mycelial ODC activity dropped to a lower level than was observed in non-induced cultures (Fig. 1a).

Supplementation with oxalic acid quickly acidified the culture fluids: with 5 and $10 \mathrm{mM}$ oxalic acid the (a)

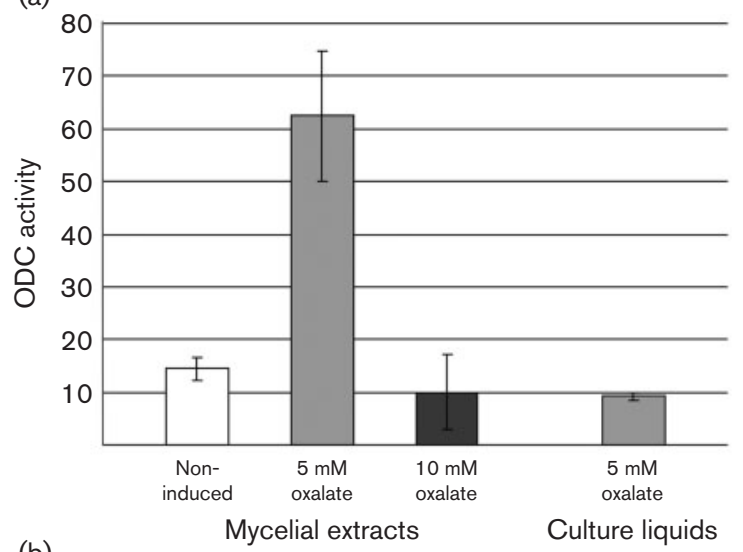

(b)

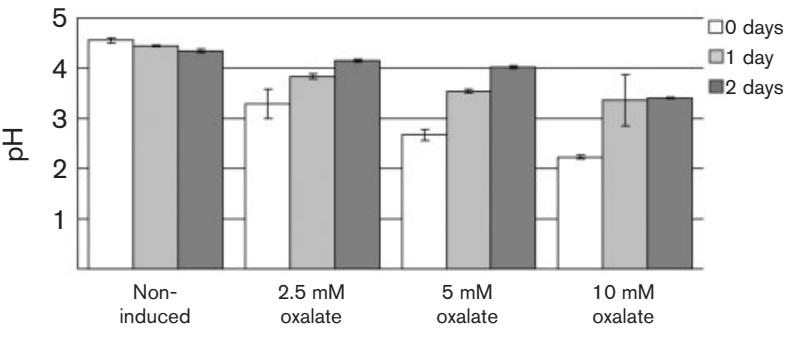

Fig. 1. Effect of supplementing submerged cultures of $D$. squalens FBCC184 with oxalic acid. (a) ODC activity [ $\mu$ mol oxalic acid decarboxylated ( $\mathrm{mg}$ protein) ${ }^{-1} \mathrm{~min}^{-1}$ ] in mycelial extracts and culture liquids 2 days after addition of $5 \mathrm{mM}$ (light grey columns) and $10 \mathrm{mM}$ (dark grey column) oxalic acid. Non-induced mycelium was cultivated without addition of oxalic acid (white columns). (b) Effect on the extracellular $\mathrm{pH}$ values immediately ( 0 days), 1 day and 2 days after addition of $2.5,5$ or $10 \mathrm{mM}$ oxalic acid. Error bars indicate the standard deviation between three parallel cultures.

extracellular $\mathrm{pH}$ immediately declined below 3 (Fig. 1b). Within 2 days, extracellular acidity settled to about $\mathrm{pH} 4$ with 2.5 and $5 \mathrm{mM}$ oxalic acid, whereas with $10 \mathrm{mM}$ oxalic acid, the $\mathrm{pH}$ stayed lower, at 3.4. In non-induced cultures the extracellular $\mathrm{pH}$ remained at 4.6 (Fig. 1b).

\section{Characterization of $\boldsymbol{D}$. squalens ODC protein}

Mycelial protein fractions with the highest ODC activities eluted at $\mathrm{pH} 4.2-4.25$ of the chromatofocusing elution buffer, which indicates that the pI value of the Ds-ODC enzyme is within this range (Fig. 2a). A minor amount of enzyme activity was also detected at $\mathrm{pH} 2.6$, which suggests marginal production of another ODC isozyme.

Western blotting with ODC antibody detection showed two protein bands, of 55 and $95 \mathrm{kDa}$, in the $5 \mathrm{mM}$ oxalic acid induced mycelial extracts from D. squalens FBCC312, whereas one ODC protein of $52 \mathrm{kDa}$ was observed in isolate FBCC184 (Fig. 2b). In the non-induced mycelial extract of $D$. squalens FBCC312, only the $95 \mathrm{kDa}$ ODC protein band was detected, possibly due to the lower 
(a)

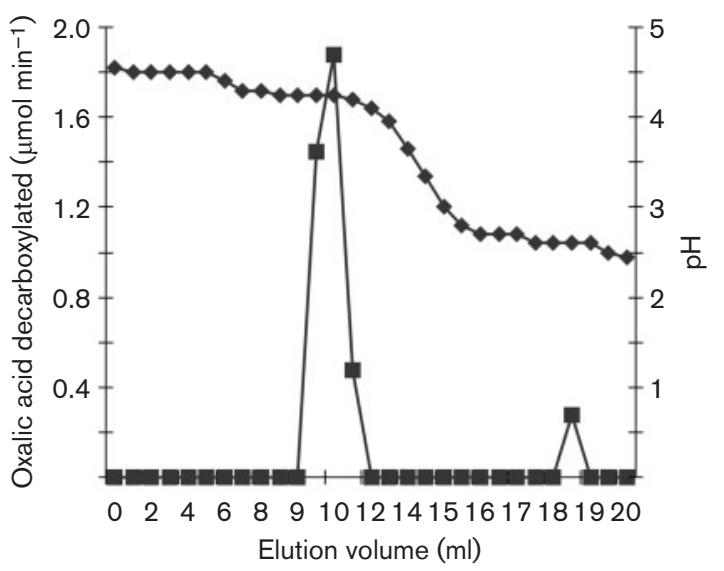

(b)

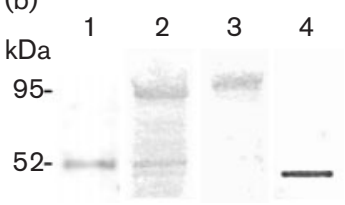

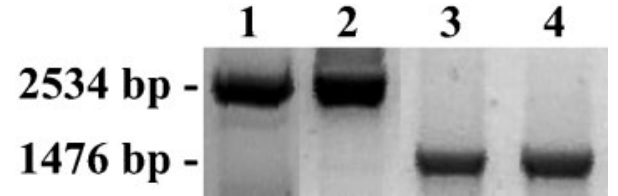

Fig. 3. The full-length $D$. squalens FBCC184 odc sequence amplified from DNA (lane 1) and the full-length $D$. squalens FBCC312 odc sequences amplified from DNA (lane 2), cDNA from submerged liquid culture (lane 3 ) and cDNA from solid-state wood culture (lane 4). Sizes of the PCR products are shown on the left.

submerged liquid and solid-state wood cultures of $D$. squalens FBCC312 (Fig. 3). The nucleotide sequences of the two $D s-o d c$ genomic clones obtained from isolates FBCC184 and FBCC 312 are both 2537 bp in length and no differences were detected in their nucleotide sequences within the ORF coding regions (exons). The coding regions are also identically interrupted with 17 introns that were similar in length between the isolate clones (Fig. 4). The genomic sequence contains one non-canonical $5^{\prime}$ splicesite junction with a GC dinucleotide instead of GT at the beginning of intron XIV. The intron length varies from $49 \mathrm{nt}$ to $91 \mathrm{nt}$ in Ds-odc, the lengths of the exons range from only $10 \mathrm{nt}$ up to $452 \mathrm{nt}$. A TATA box is found $62 \mathrm{bp}$ upstream of the start codon (ATG). One putative metal response element (MRE), one CCAAT box, and two cyclic AMP responsive elements are found at $55 \mathrm{bp}, 334 \mathrm{bp}, 354 \mathrm{bp}$ and $411 \mathrm{bp}$ upstream of the start codon, respectively (Fig. 4).

Ds-odc ORF codes for a putative 493 aa polypeptide with the conserved bicupin primary structure as defined for one cupin motif as $\mathrm{G}(\mathrm{X})_{5} \mathrm{HXH}(\mathrm{X})_{3-4} \mathrm{E}(\mathrm{X})_{6} \mathrm{G}$ followed by $\mathrm{G}(\mathrm{X})_{5} \mathrm{PXG}(\mathrm{X})_{2} \mathrm{H}(\mathrm{X})_{3} \mathrm{~N}$, with $15-27$ aa in the intermotif region (Dunwell \& Gane, 1998; Dunwell et al., 2000) (Fig. $5)$. The conserved residues of three histidines and one glutamate, which are known to bind one $\mathrm{Mn}^{2+}$ ion, are present in both of the cupin motifs. A putative secretion signal peptide of 20 aa at the $5^{\prime} \mathrm{N}$-terminus is predicted with the SignalP 3.0 program (http://www.cbs.dtu.dk/ services/SignalP/) (Fig. 4). According to the general eukaryotic rule for $\mathrm{N}$-glycosylation (N-X-S/T, where $\mathrm{X}$ is not $\mathrm{P}$ ), four potential glycosylation sites are found in the translated protein. Two of the predicted $N$-glycosylation sites reside in the $\mathrm{N}$-terminus within an approximately 60 aa alanine-serine-rich stretch that is located in conjunction to

One Ds-odc ORF of $1479 \mathrm{bp}$ was amplified from the cDNAs originating from mycelia obtained from both

Fig. 4. Nucleotide and translated amino acid sequences of the $D$. squalens odc gene. Exons are in capital letters, and introns and $5^{\prime}$ and $3^{\prime}$ UTR sequences in small letters. The $3^{\prime}$ UTR sequence amplified from the cDNA until poly(A) is in italics. Introns are numbered I-XVII. The non-canonical 5' splice site of intron XIV with a GC dinucleotide is in bold and double-underlined. The stop codon is marked with *, amino acids involved in $\mathrm{Mn}^{2+}$ binding with $\boldsymbol{\nabla}$, and putative $N$-glycosylation sites with $\mathbf{\square}$. The $5^{\prime}$ promoter sequence is numbered negatively upstream from the translational start codon (ATG). The TATA box is in bold and the CCAAT box is underlined. Predicted regulatory elements are underlined and marked as CREB (cyclic AMP responsive element binding protein) and MRE (metal response element). The putative N-terminal secretion signal peptide is highlighted in grey. 


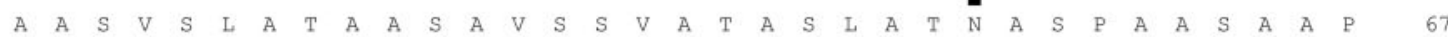
CCGCAGCGAGCGTGTCCCTCGCGACCGCCGCATCTGCGGTATCTTCCGTAGCTACTGCCTCCCTTGCGACGAACGCGTCCCCCGCGGCCAGCGCAGCCCC 200

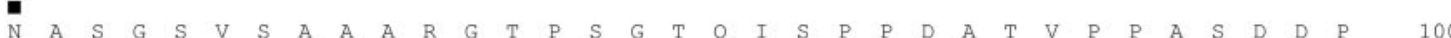
CAACGCTAGCGGCTCTGTGTCTGCGGCTGCACGAGGCACCCCTTCGGGGACCCAGATTTCTCCGCCGGATGCCACTGTACCACCCGCGAGCGATGACCCC 300

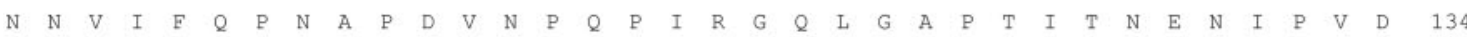
AACAACGTGATCTTCCAGCCTAACGCCCCCGACGTCAACCCCCAGCCAATTCGTGGGCAGCTCGGCGCCCCCACGATCACCAACGAGAACATTCCTGTCG 400

$\begin{array}{lllllllllllllllllll}V & Q & N & P & D & L & L & A & P & P & S & T & D & H & G & E & F & \text { intron } & \text { I }\end{array}$ ACGTGCAGAACCCAGATCTGCTCGCACCGCCGTCGACGGACCATGGGGAATTgtatgtgcetccettgaactctgetgtgtgcetgaaaagacctggacg

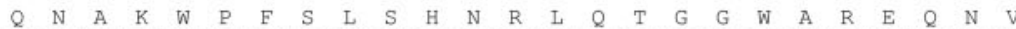
cgtgttgacttgcggtacgaatatagCCAGAACGCAAAGTGGCCGTTCAGTCTCAGCCATAACCGTCTACAGACAGGAGGCTGGGCCCGTGAGCAGAACG

intron II

gtatgtctcgtataggcettggttgaggcgtgggggetatgccacccacgagtgegtctgactgagggctgacgaaaccttatcatcacagTCGGTGTCA

$P$ I $S$ T $S$

intron III

$\begin{array}{lllllllllllllllllll}M & A & G & V & N & M & R & L & E & A\end{array}$

151

TGCCCATCTCAACCTgtgagtcatagccgttgcgtctaactataggcagccagctcaagtccaatgcagCTATGGCCGGTGTGAATATGCGTCTGGAAGC

G A V R

intron IV

E $\begin{array}{lllllllll}\mathbf{V} & \mathrm{H} & \mathrm{W} & \mathrm{H} & \mathrm{K} & \mathrm{T} & \mathrm{S} & \mathrm{E}\end{array}$

TGGGGCAGTTCGgtgagtgtccaattacgccatcttcatcccttgcacttgctcacaagggctattagGGAGCTGCATTGGCACAAGACTTCTGAGgtat

intron $\mathrm{V}$

W A Y I I N

agtaatcttcgtatccgtgacctccgatgttaccgaggttgctaatgcgatgtgtggcatctcccaaagTGGGCATATATCCTGAACgtatgtcaggttt

intron VI

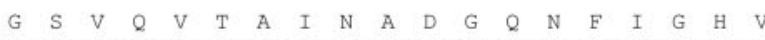
acctcgtgaagcgcaaacttgctgatatctcgtccagGGTTCCGTCCAAGTGACTGCTATCAATGCGGATGGCCAGAACTTCATCGGGCACGTGgtaagt

intron VII

N P G D L W F F P A G M P H

176 600 acagCTGACTGATTGGTTGTCGCACATTCCCAAGGAAGTCATCGCCAAAAACTTCCAGACCAGCATCTCCGCCTTCAACAACCTTCCCAGCCAGGAACTA 1500

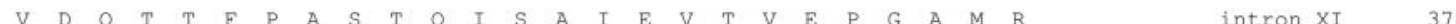
TGTCGACCAGACTACTTTCCCGGCTTCGACCCAGATCTCTGCGATCGAGGTGACAGTCGAGCCTGGTGCTATGAGgttcgccettggtctatatcaactt 1800

$$
\text { E I }
$$


the secretion leader peptide, all encoded by an exceptionally long exon of $452 \mathrm{bp}$ prior to the first intron (Fig. 4). The theoretical $\mathrm{pI}$ value and molecular mass of the mature DsODC are 4.6 and $50 \mathrm{kDa}$, respectively, as determined by bioinformatic calculations (http://au.expasy.org/).

Ds-ODC shows the highest pairwise amino acid identity of $60 \%$ with two putative Phanerochaete chrysosporium ODCs encoded by potential genes annotated within the whole genome sequence (e_gwh2.16.56.1 and e_gwh2.5.232.1, http://genome.jgi-psf.org/Phchr1/Phchr1.home.html) (Fig. $5)$. When the exon-intron structures of odc genes are compared, the $5^{\prime}$ end of Ds-odc resembles the corresponding region of the F. velutipes odc while at the $3^{\prime}$ end of Dsodc the intron positioning is more similar to that of the putative odc gene annotated in the whole genome sequence of Laccaria bicolor (Fig. 6). The D. squalens and F. velutipes sequences contain 17 introns but four of the introns, nos
XII and XIV in $D s-o d c$, and nos X and XIV in $F v-o d c$, are found in non-equivalent positions (Fig. 6).

In the evolutionary tree of ODC and oxalate oxidase (OXO) amino acid sequences, the Ds-ODC groups within the main branch of ODCs from other basidiomycetous fungi (Fig. 7). The ODCs from ascomycetes and bacteria form two separate clusters or clades within the tree. Quite exceptionally, two of the seven putative ODC sequences from $P$. chrysosporium fall into the same branch with ascomycetous sequences. In fact, these two putative $P$. chrysosporium ODCs were significantly shorter as translated proteins. Also, the Ceriporiopsis subvermispora bicupin OXO clusters closest to the Trametes versicolor ODC, whereas the monocupin plant OXO from wheat (Triticum aestivum) was the shortest and most divergent in amino acid sequence, thus acting as a far-relative outgroup in the neighbour-joining tree.

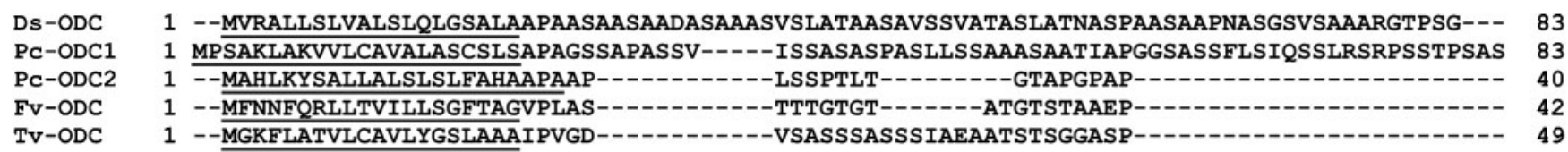

DS-ODC 84 TQISPPDATVPPASDDPNNVIFQPNAP--DVNPQPIRGQLGAPTITNENIPVDVQNPDLLAPPSTDHGEFQNAKWPFSLSHNRLQTGG 169 PC-ODC1 84 LSAPPASETVPYASDDANTVVWSPGWD--GQPE-AIRGSLGSSVMGPQNDPIDLQNPDLLAPPTTDAGTVGNAKWPFSLSHNRLQTGG 168 PC-ODC2 41 -------TVPYASDDPNVEIYPPNINDPGYVPEPIRGKLGSNILAQHNIPLALENPTLLAPPTTDHGSIPNAHWPFSLSHNRLQTGG 120 FV-ODC 43 ------SATVPFASTDPNPVLWNETSD--PALVKPERNQLGATIQGPDNLPIDLQNPDLLAPPTTDHGFVGNAKWPFSFSKQRLQTGG 123 Tv-ODC 50 ------SPTVPLASDDPNYWLWNETTT--TDPQ-PERGSLGANILGPQNVAIDKQNPDILAPPTTDQGTVGNAKWPFSLSKQQLNTGG 128

CUPIN 1
DS-ODC 170 WAREQNVGVMPISTSMAGVNMRLEAGAVRELHWHKTSE̋WAYILNGSVQVTAINADGQNFIGHVNPGDLWFFPAGMPḦSLQATNENPDG 257 PC-ODC1 169 WARQQNLAVLPMATEMAGVDMRLEVGAIRELHWHKTGEWAYVLQGSVQISAVNQNGQNFVSTVSQGDLWYFPAGVPHSIQATDANPNG 256 PC-ODC2 121 WARQQNVNEMPFAKNLAGVDMRLEAGAIRELHWHSTAEWAYVLDGTMQITTVTPEGQNYIGTIHPGDLWYFPPGQPHSLQATADNPQG 208 Fv-ODC 124 WARQQNEVVLPLATNLACTNMRLEAGAIRELHWHKNAEWAYVLKGSTQISAVDNEGRNYISTVGPGDLWYFPPGIPHSLQATADDPEG 211 TV-ODC 129 WVRQQNVQQMPIATAMAGVNMRLESGAIRELHWHQTAEWAYVLSGSTQISSVDQLGRNYVATVRQGDLWYFPPGIPHSLQATNDSSEG 216 $\boldsymbol{\nabla}$

DS-ODC 258 AEFVLVFPDGSFSEDSTFLLTDWLSHIPKEVIAKNFQTS-ISAFNNLPSQELYIFPSTPPPVNQQPPSDPQGTIPQPWTFALSQVKAT 344 PC-ODC1 257 AEFLLVFDDGNFSEDDTFLLTDWLAHVPKDVLAKNFQTS-MSTFDKLPGKELYIFPAAPPGPDSDAPTSPQGTVPNPFTFKLSGMPAT 343 PC-ODC2 209 AEFLLVFDNGTFNEGATFLLTDWLAHVPKEVIAKNFQTS-IAAFERIPDQELYIFPSNPPPDDQQPPTSPYGTTPEPYTYEFSKVPVT 295 Fv-ODC 212 SEFILVFDSGAFNDDGTFLLTDWLSHVPMEVILKNFRAKNPAAWSHIPAQQLYIFPSEPPADNQPDPVSPQGTVPLPYSFNFSSVEPT 299 TV-ODC 217 TEFLLIFPDGNFNDDDTLLLTDWLAHTPKEVIAKNFQDN-IADWDDIPGSQLYIFPGVPPPDNQQPPTSPAGEIPQPFSYAFSEITPT 303

$\begin{array}{ll}\text { DS-ODC } 345 \text { QVQGGTIKIVDQTTFPASTQISAIEVTVEPGAMREIḦWHPTQDËWTFYISGQGRVTIFAGTSTSRTFDYQAGDVGFVPASMGHFVENT } 432 & \text { CUPIN } 2\end{array}$ PC-ODC1 344 QLQGGSVKIVDSNTFKASKTIAAAEVTVEPGAMRELHWHPTQDEWSYFISGNARVTLFAAQSSARTFDYQPGDVAYIPGSYGHYVENI 431 PC-ODC2 296 QVPGGTFKIADSTTFKVSKTIAVAEFTVEPGALRELHWHPTFDEWTYFLEGQARMTLFAAESNARTFDYQAGDIGYVPASYGHYIENT 383 FV-ODC 300 QYSGGTAKIADSTTFNISVAIAVAEVTVEPGALRELHWHPTEDEWTFFISGNARVTIFAAQSVASTFDYQGGDIAYVPASMGHYVENI 387 TV-ODC 304 QYTGGTAKIADSTTFKVATKIAVAEVTVEPGAMREMHWHPTQSEWGFFLEGTARVTLFAGTAIAQTFDYQPGDISYIPTAYGHYVENT 391

DS-ODC 433 GNDTLHFLELFPSGIVQDVSLRQWLALTPPELVQVHLGIDQDTLNQLTSFKTKEFVVG--PSQ--PC-ODC1 432 GNDTLHYLEIFKTDTFQDVSLSQWLALTPPDMVKATLNLDDEALKHFSK--TKPVVVG--PSKGSS PC-ODC2 385 GNTTLKFLEIFKTDRFQDVSLSQWLALTPPELVKAHLGISDETVQHLSK--TKPMVVAPYTPAENFV-ODC 388 GNTTLTYLEVFNTDRFADVSLSQWLALTPPALVKQHLQLSDETLAELKQFATKATVVG--PVN--TV-ODC 392 GNTTLKFLEIFNSDVFQDVSLAQWLALTPPALVKQHLQLSDATISRFNR--TKGVVVGGPGANVSS

Fig. 5. Comparison of translated amino acid sequences of white-rot fungal ODCs by CLUSTAL w (http://www.ebi.ac.uk/Tools/ clustalw/) multiple alignment. Putative $\mathrm{N}$-terminal signal peptide sequences are underlined, two cupin motifs are highlighted in grey, conserved amino acid residues involved in the binding of $\mathrm{Mn}^{2+}$-ions are marked with *, and the amino acid position corresponding to Glu162 in Bacillus subtilis OxdC is marked with $\boldsymbol{\nabla}$. Fungal species, their abbreviations, and sequence accessions in the EMBL Nucleotide Sequence Data Bank or in Uniprot are: Dichomitus squalens FBCC312, Ds-ODC, FM946037 and FM955140; Flammulina velutipes Fv-ODC, Q9UVK4; and Trametes versicolor Tv-ODC, Q6UGB9. Translated sequences for two of the whole genome sequence annotated genes of Phanerochaete chrysosporium (Pc-ODC1, e_gwh2.5.232.1; Pc-ODC2, e_gwh2.16.56.1) were retrieved from the DOE Joint Genome Institute (http://genome. jgi-psf.org/Phchr1/Phchr1.home.html). 


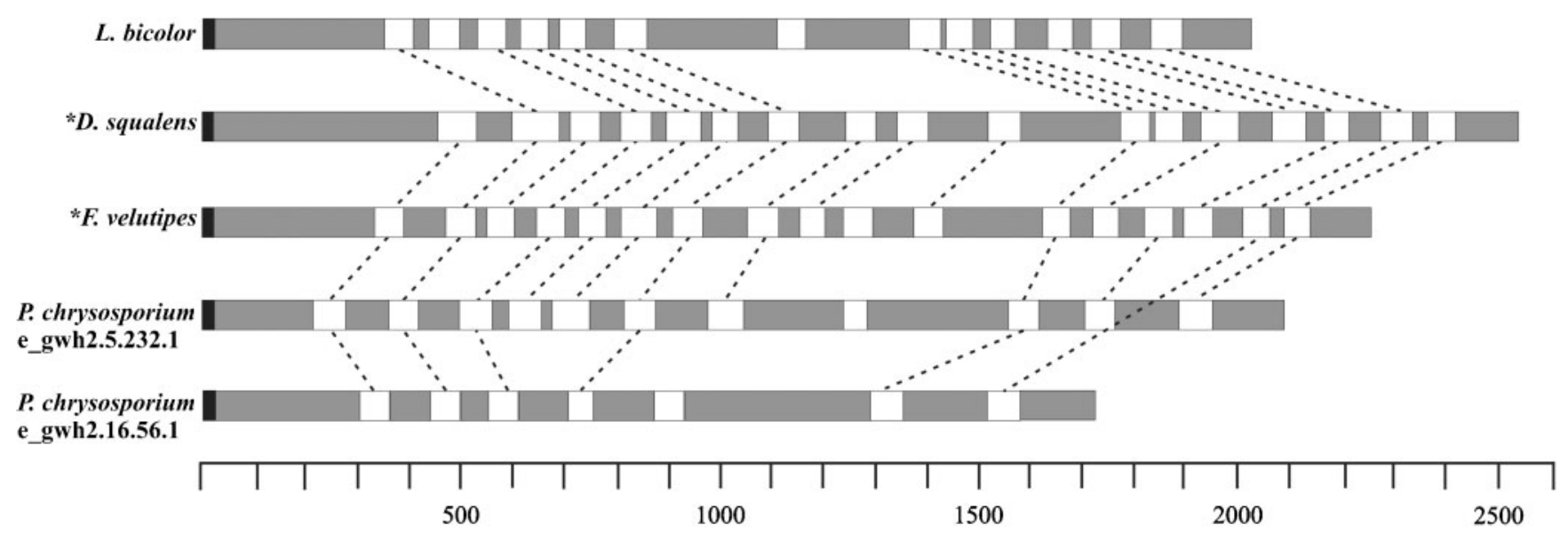

Fig. 6. Exon-intron structure analysis of ODC-encoding genes from the basidiomycetous fungi Dichomitus squalens (this study), Flammulina velutipes, Laccaria bicolor and Phanerochaete chrysosporium. The odc genes cloned and characterized at the protein level are marked with *. Black, grey and white boxes represent putative secretion signal peptides, exons and introns, respectively. The scale bar shows sequence length in nucleotides. Introns in equivalent positions are connected with dashed lines. Gene sequence accession numbers are FM946037 for D. squalens, AF200683 for F. velutipes and DS547157 for the predicted protein annotated in the whole genome sequence of $L$. bicolor. $P$. chrysosporium annotated sequences e_gwh2.5.232.1 and e_gwh2.16.56.1 were retrieved from the DOE Joint Genome Institute (see the legend for Fig. 5).

\section{Expression of Ds-odc in solid-state wood and submerged cultures}

Real-time qRT-PCR showed that Ds-odc gene is expressed during the fungal growth on solid-state wood cultures after 3 and 4 weeks of cultivation (Fig. 8a). With the samples taken after 1 and 2 weeks of solid-state cultivation, cDNA synthesis did not succeed, most probably due to minor growth of fungus and too low a yield of total RNA. After 4 weeks, the amount of Ds-odc transcripts decreased to almost half of the amount detected after 3 weeks of cultivation. In the submerged cultures, addition of excess oxalic acid was not observed to induce expression of Ds-odc at the transcriptional level, as the highest amount of transcripts was observed in the cultures without supplementation of oxalic acid (Fig. 8b). In the submerged cultures where oxalic acid was added to give $5 \mathrm{mM}$ final concentration, a decline in the quantity of Ds-odc transcripts was detected compared to the non-induced cultures (Fig. 8b). With $2.5 \mathrm{mM}$ oxalic acid, the lowest amount of Ds-odc transcripts was obtained. The transcriptspecific qRT-PCR primers designed for the Ds-odc and Dsgapdh amplicons (Table 1) resulted in amplification of PCR products of the correct size, with a $116 \mathrm{bp}$ and $49 \mathrm{bp}$ DNA fragment length difference, respectively, from the corresponding genomic DNA products (Fig. 8c).

\section{DISCUSSION}

In this study, we cloned and performed preliminary characterization of a new oxalate decarboxylase (DsODC) from two isolates of the lignin-degrading white-rot fungus Dichomitus squalens. ODC is a relevant enzyme for biotechnological applications due to its ability to specifically decompose oxalic acid, with prospects from process industry to diagnostics. So far, only one fungal ODC has been completely cloned and enzymically described, from Flammulina (Collybia) velutipes (Mehta \& Datta, 1991; Kesarwani $e t$ al., 2000). To add to the pool of fungal ODCs, we focused on identifying the gene and enzyme from $D$. squalens, which showed high ODC activity in our previous screening study (Mäkelä et al., 2002).

The primary characterization of Ds-ODC demonstrates a 493 aa protein of conserved bicupin core structure containing a unique alanine-serine-rich stretch of over 60 aa residues in the $\mathrm{N}$-terminus directly after the putative secretion signal peptide. The ODC protein was also identified by immunohybridization in the mycelial extracts of the two D. squalens isolates. Most of the ODC activity was observed to be associated with the $D$. squalens mycelium while a small proportion of activity was detected in the extracellular culture liquid. Real-time qRT-PCR showed that the Ds-odc gene was expressed both on solidstate wood and in submerged liquid cultures, even without addition of excess oxalic acid, thus pointing to the importance of the ODC enzyme for general metabolism and growth of the fungus.

Ds-odc transcripts were detected and quantified during weeks 3 and 4 of cultivation of $D$. squalens on spruce wood sticks. This is consistent with our former results showing that $D$. squalens secretes oxalic acid together with production of manganese peroxidase after a similar cultivation period on spruce wood, with acidity staying at pH 4.1-4.4 (Mäkelä et al., 2002). In the present study, the amount of Ds-odc transcripts was observed to decline in 


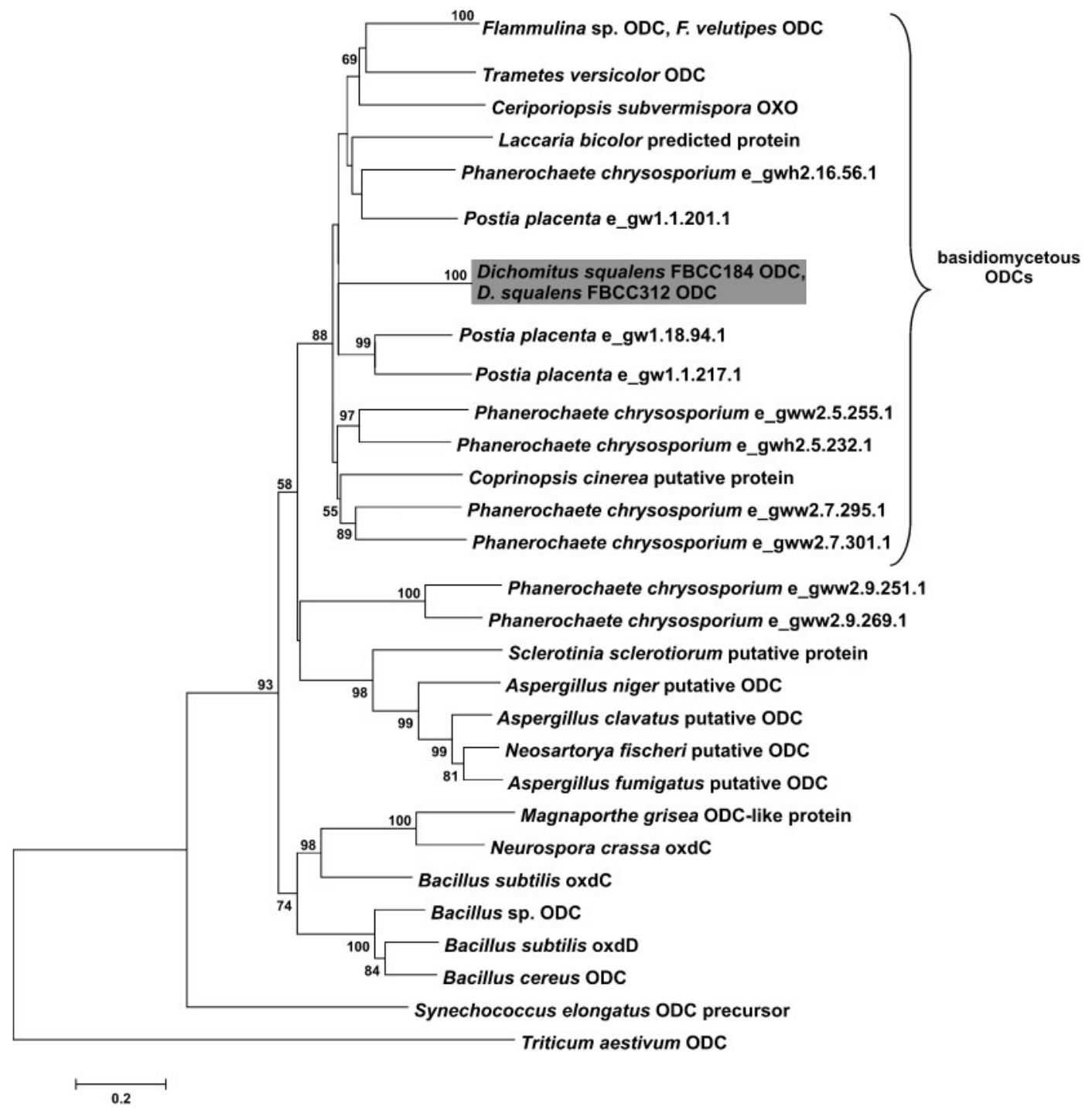

Fig. 7. Evolutionary relations of selected and putative oxalate decarboxylase (ODC) and oxalate oxidase (OXO) amino acid sequences of microbial and plant origin depicted in a minimum-evolution neighbour-joining tree. Bootstrap values (1000 replications) higher than $50 \%$ are indicated for the nodes. The scale bar shows a distance equivalent to 0.2 amino acid substitutions per site. Species name and Uniprot or EMBL Nucleotide Sequence Data Bank sequence accessions are: Aspergillus clavatus putative ODC (A1C785), A. fumigatus putative ODC (Q4X060), A. niger contig An15c0140 from complete genome (A5ABZ4), Bacillus sp. ODC (A3IBX7), B. cereus ODC (Q81GZ6), B. subtilis OxdC (O34714), B. subtilis OxdD (O34767), Ceriporiopsis subvermispora OXO (Q5ZH56), Coprinopsis cinerea putative protein (A8NVA5), Dichomitus squalens FBCC184 ODC (FM954981), D. squalens FBCC312 ODC (FM946037), Flammulina sp. ODC (Q870M8), F. velutipes ODC (Q9UVK4), Laccaria bicolor predicted protein (BODZS6), Magnaporthe grisea ODC-like protein (Q5EMV1), Neosartorya fischeri putative ODC (A1DI17), Neurospora crassa OxdC (Q7SFG6), Sclerotinia sclerotiorum putative uncharacterized protein (A7EZM9), Synechococcus elongatus ODC precursor (Q31KK1), Trametes versicolor ODC (Q6UGB9), Triticum aestivum OXO (P15290). The following putative ODC sequences were retrieved from the DOE Joint Genome Institute (http://genome.jgi-psf.org/) whole genome sequence websites: Phanerochaete chrysosporium e_gww2.5.255.1, e_gwh2.5.232.1, e_gww2.7.295.1, e_gww2.9.251.1, e_gww2.9.269.1, e_gwh2.16.56.1 and e_gww2.7.301.1 and Postia placenta e_gwl.18.94.1, e_gw1.1.201.1 and e_gw1.1.217.1.

week 4, which coincides with the decrease in oxalic acid concentration on spruce wood (Mäkelä et al., 2002). Previously, ODC was demonstrated after the growth of Trametes (Coriolus) versicolor on beech wood (Dutton et al.,
1994), and more recently Phanerochaete chrysosporium was reported to expresses ODC protein on oak wood cultures together with key enzymes involved in fungal metabolism of lignocellulose (Sato et al., 2007). 
(a)

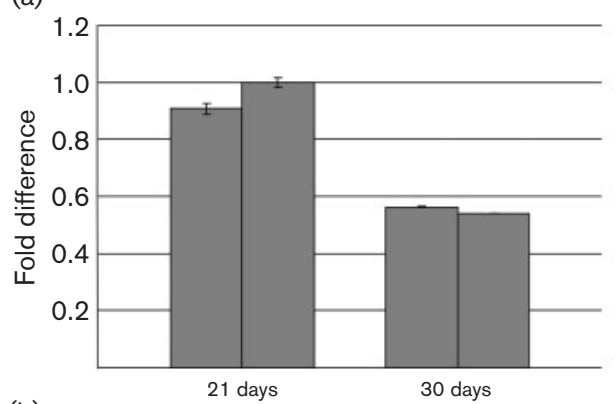

(b)

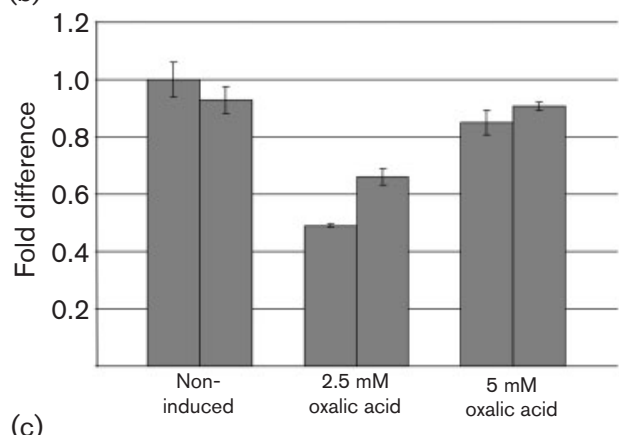

(c)

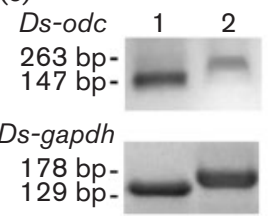

Fig. 8. (a) Expression level of $D$. squalens odc in solid-state wood cultures after 3 and 4 weeks of incubation, as detected by realtime qRT-PCR. (b) Expression level of $D$. squalens odc in $2 \%$ liquid malt extract medium either without or after addition of 2.5 or $5 \mathrm{mM}$ oxalic acid, as detected by real-time qRT-PCR. Two columns at each time point and treatment represent biological replicates. Error bars indicate the standard deviation between three replicate qPCRs. (c) Sizes of the PCR products from cDNA (lane 1) and genomic DNA (lane 2) amplified with gene-specific primer pairs designed to $D$. squalens ODC and GAPDH-encoding genes and used in real-time qRT-PCR.

To our surprise, Ds-odc was not upregulated at transcriptional level by addition of excess oxalic acid (2.5-5 mM), even though mycelial ODC activities were noticeably promoted by treatment with $5 \mathrm{mM}$ oxalic acid. In contrast to the enzyme activities, the Ds-odc transcript levels were somewhat suppressed by these levels of extracellular oxalic acid, at least 1 day after the treatment in the submerged cultures. The highest level of transcripts was obtained with non-induced cultures where the extracellular acidity was kept at $\mathrm{pH} 4.4$.

It is noteworthy that extracellular $\mathrm{pH}$ dropped to 2.7 immediately after introducing $5 \mathrm{mM}$ oxalic acid. Our results differ from the data reported for the woodcolonizing basidiomycete $F$. velutipes, where the odc gene was induced at the transcriptional level at low $\mathrm{pH}(3.0)$ without supplementation of exogenous oxalic acid (Azam et al., 2002). The promoter region -287 to $-278 \mathrm{bp}$ upstream of the $F$. velutipes odc contains a low-pH responsive element, and a protein complex specifically binding to the promoter has been identified (Azam et al., 2002). In our case, this type of element was not recognized within the $428 \mathrm{bp} 5^{\prime}$ promoter region of D. squalens odc. Likewise, the Bacillus subtilis ODC enzyme activity is inducible at acidic $\mathrm{pH}$, independently of addition of oxalic acid (Tanner \& Bornemann, 2000). The promoting effect of excess oxalic acid that was observed in our study for ODC activity in D. squalens may also indicate some kind of protein- or enzyme-level activation, which may be either due to low $\mathrm{pH}$ and extracellular acidity or specifically caused by oxalic acid.

The Ds-odc gene was cloned from the two isolates of $D$. squalens. The two genes were identical in sequence at the nucleotide level in the ORF coding regions (exons), and the introns were identically positioned and similar in length. $D s$-odc shows a high number (17) of short introns, which vary in length from 49 to $91 \mathrm{nt}$. The ODC-encoding gene from $F$. velutipes also contains 17 small introns (Kesarwani et al., 2000). Characteristically, the Ds-odc possesses two very short exons, only 10 and $18 \mathrm{nt}$ in length. Of these, one is in the first cupin motif region, and the other is in the second cupin region (Fig. 4); this is again comparable with the F. velutipes odc, which contains two short exons of 18 and $21 \mathrm{nt}$ in similar locations (Kesarwani et al., 2000).

One of the striking features of the $D s$-odc gene is the existence of one non-canonical $5^{\prime}$ splice site in intron XIV with a GC dinucleotide at the beginning. The most common class of non-canonical intron splice sites in mammals is identically reported to consist of $5^{\prime}$ splice sites with a GC dinucleotide (Wu \& Krainer, 1999). In fungi, the percentage of introns with $5^{\prime}$-GC...AG-3' splice sites is reported to be $0.08 \%, 0.86 \%, 1.15 \%$ and $1.19 \%$ for the ascomycetes Schizosaccharomyces pombe, Neurospora crassa, Aspergillus nidulans and Saccharomyces cerevisiae, respectively, and even higher, $1.98 \%$, for the basidiomycetous yeast Cryptococcus neoformans (Kupfer et al., 2004; Rep et al., 2006). In the white-rot basidiomycete Ceriporiopsis subvermispora, one allele of its oxo gene has also been reported to contain one intron with GC instead of GT at the 5' splice site (Escutia et al., 2005).

D. squalens was observed to produce two acidic ODC isozymes with pI values of 4.2 and 2.6 , which is similar to the ODCs in the litter-decomposing basidiomycete Agaricus bisporus with pI values of 3.4 and 3.0 (Kathiara et al., 2000), in F. velutipes with pI values of 3.3 and 2.5 (Mehta \& Datta, 1991), and in T. versicolor with $\mathrm{pI}$ values of 3.0 and 2.3 (Dutton et al., 1994). The molecular mass of the $D$. squalens ODC bicupin monomer, $52-55 \mathrm{kDa}$ as estimated by SDS-PAGE, is slightly lower than those reported for the ODCs from A. bisporus (64 kDa) (Kathiara et al., 2000), F. velutipes (64 $\mathrm{kDa}$, deglycosylated enzyme $55 \mathrm{kDa}$ ) (Mehta \& Datta, 1991), and T. versicolor (59 kDa) 
(Dutton et al., 1994). The functional D. squalens ODC is presumably a hexamer and approximately six times larger in terms of kilodaltons, as has been shown for the active $F$. velutipes ODC, with a molecular mass of $420 \mathrm{kDa}$ under non-denaturing conditions (Chakraborty et al., 2002).

With respect to the structural and functional similarities between ODC and OXO, and the first protein crystal structures available, their conserved Mn-binding sites have been compared (Svedružić et al., 2005). Five amino acids, and especially Glu162 in B. subtilis ODC (OxdC), forming the so-called lid structure extending over one Mn-binding cupin site, seem to have a crucial role in binding of oxalic acid and the formic anion product, thus determining the specificity of oxalate oxidation and cleavage (Just et al., 2004, 2007; Burrell et al., 2007).

Burrell et al. (2007) showed with B. subtilis ODC that a mutation in Glu162 can convert the decarboxylase (ODC) activity into oxidase (OXO) activity. Ds-ODC also has a glutamate residue in the corresponding position (Glu271, Fig. 5), confirming its nature as a true ODC enzyme producing formic acid and $\mathrm{CO}_{2}$ in the catalytic cycle. Multiple alignment of ODC sequences from basidiomycetous fungi shows that the $F$. velutipes and $T$. versicolor enzymes have a corresponding acidic residue, an aspartate, in this position (Fig. 5). Within the B. subtilis ODC, mutated aspartate in this position has been shown to lower the catalytic efficiency, but not the specificity of ODC (Svedružić et al., 2007).

In spite of the $\mathrm{N}$-terminal secretion signal peptide predicted in the Ds-ODC, most of the ODC activity was found in the mycelial extracts of D. squalens irrespective of the oxalic acid supplementation. This is consistent with observations for the ODC activities in T. versicolor, with 620 times lower activities detected in culture fluids than in the mycelial extracts (Dutton et al., 1994). In A. bisporus, most of the ODC protein was located intracellularly (Kathiara et al., 2000). In the brown-rot fungus Postia placenta, most of the ODC activity was observed on the surface of the fungal hyphae, while minor enzyme activities were detected intracellularly or in the culture filtrates (Micales, 1997).

These results raise a question regarding the location of ODC as a predominantly intracellular or fungal-cell-wallassociated enzyme, in spite of the existence of putative secretion signals in the white-rot fungal ODC amino acid sequences (Fig. 5), also present in the N-terminus of DsODC. However, the possible targeting or signalling role of the $\sim 60$ aa alanine-serine-rich stretch in the $\mathrm{N}$-terminus of the Ds-ODC is as yet unknown to us. A similar motif is present in some of the putative P. chrysosporium ODCs, and in a shorter form $(\sim 20 \mathrm{aa})$, it can be observed also in the T. versicolor ODC (Fig. 5).

As expected, Ds-ODC shows closest identity with the translated ODC protein sequences from other basidiomycetous fungi, with the highest pairwise identity $(60 \%)$ to putative $P$. chrysosporium ODC sequences. In a previous study, when the conserved motif regions of proteins belonging to the cupin superfamily were analysed, bacterial and fungal ODCs formed one monophyletic clade (Khuri et al., 2001). According to our phylogenetic analysis with the translated full-length ORF protein sequences, however, bacterial and fungal ODCs fall into several subclusters, indicating a diverse ODC enzyme family (Fig. 7). Most of the amino acid sequence dissimilarities are within the $\mathrm{N}$ terminal regions.

Within our evolutionary tree, the basidiomycetous ODCs clustered within a main branch of their own (Fig. 7). The only exceptions to this were the two putative ODCencoding sequences within the seven candidates recognized in the P. chrysosporium genome. The two exceptional sequences were the shortest, and clearly separated from the basidiomycetous and ascomycetous ODC branches. The basidiomycetous ODC cluster also includes the bicupin OXO cloned from C. subvermispora, thus confirming the very close evolutionary relationship of the Cs-OXO to the ODC proteins, which is in accordance with the previous suggestion of Escutia et al. (2005).

To our knowledge, C. subvermispora is the first fungus from which both ODC and OXO activities have been measured (Aguilar et al., 1999; Watanabe et al., 2005), and a scheme for the participation of both enzymes in the fungal metabolic reactions and lignin degradation has been proposed (Watanabe et al., 2005). Furthermore in C. subvermispora, ODC is suggested to act sequentially with formate dehydrogenase (FDH). This will lead to complete conversion of oxalic acid to $\mathrm{CO}_{2}$ with concomitant generation of $\mathrm{NADH}$, which can be used as an electron source for ATP synthesis during vegetative growth of the fungus. A similar mechanism may also operate in all ODCproducing white-rot fungi, and $\mathrm{FDH}$ activity has in fact been detected in F. velutipes, $P$. chrysosporium and $T$. versicolor (Watanabe et al., 2005). Very recently with the brown-rot fungus Postia placenta, transcripts of one putative ODC, three putative FDHs and one putative formate transporter-encoding gene were shown to be upregulated in cellulose media, and a physiological relationship between these genes was proposed (Martinez et al., 2009). On the other hand, C. subvermispora OXO has been suggested to contribute more to lignin biodegradation by generating extracellular $\mathrm{H}_{2} \mathrm{O}_{2}$, which is needed for example in the catalysis of the lignin-modifying peroxidases during fungal secondary metabolism (Escutia et al., 2005; Watanabe et al., 2005).

Our data indicate that expression of the novel Ds-odc gene characterized in this work is not induced at the level of transcription by addition of oxalic acid or extracellular acidity. These findings do not exclude the possibility that the Ds-ODC enzyme may be activated at the protein level by oxalic acid or increasing acidity. These notions imply a constitutive metabolic role for the $D$. squalens ODC. The enzyme could operate in tight conjunction with formic 
acid conversion and energy generation in fungi, as was by proposed Watanabe et al. (2005). It is predictable that more than one odc gene exists also in $D$. squalens. These results indicate that fungal ODCs have variant regulatory responses, and thereby diverse metabolic roles, for the wood-decaying fungi.

\section{ACKNOWLEDGEMENTS}

Viikki Graduate School in Molecular Biosciences (VGSB) doctoral study position for M. R. M., and financial support from the Academy of Finland (research grants no. 124160 to A.H., 129869 to T.K. L., 205027 and 212303 to K. H.), are gratefully acknowledged.

\section{REFERENCES}

Aguilar, C., Urzúa, U., Koenig, C. \& Vicuña, R. (1999). Oxalate oxidase from Ceriporiopsis subvermispora: biochemical and cytochemical studies. Arch Biochem Biophys 366, 275-282.

Anand, R., Dorrestein, P. C., Kinsland, C., Begley, T. P. \& Ealick, S. E. (2002). Structure of oxalate decarboxylase from Bacillus subtilis at 1.75 A resolution. Biochemistry 41, 7659-7669.

Anantharam, V., Allison, M. J. \& Maloney, P. C. (1989). Oxalate: formate exchange. The basis for energy coupling in Oxalobacter. J Biol Chem 264, 7244-7250.

Azam, M., Kesarwani, M., Chakraborty, S., Natarajan, K. \& Datta, A. (2002). Cloning and characterization of the 5 '-flanking region of the oxalate decarboxylase gene from Flammulina velutipes. Biochem J 367, 67-75.

Burrell, M. R., Just, V. J., Bowater, L., Fairhurst, S. A., Requena, L., Lawson, D. M. \& Bornemann, S. (2007). Oxalate decarboxylase and oxalate oxidase activities can be interchanged with a specificity switch of up to 282,000 by mutating an active site lid. Biochemistry 46 , 12327-12336.

Chakraborty, S., Chakraborty, N., Jain, D., Salunke, D. M. \& Datta, A. (2002). Active site geometry of oxalate decarboxylase from Flammulina velutipes: role of histidine-coordinated manganese in substrate recognition. Protein Sci 11, 2138-2147.

Chang, S., Puryear, J. \& Cairney, J. (1993). A simple and efficient method for isolating RNA from pine trees. Plant Mol Biol Rep 11, 113-116.

Dias, B. B. A., Cunha, W. G., Morais, L. S., Vianna, G. R., Rech, E. L., de Capdeville, G. \& Aragão, F. J. L. (2006). Expression of an oxalate decarboxylase gene from Flammulina sp. in transgenic lettuce (Lactuca sativa) plants and resistance to Sclerotinia sclerotiorum. Plant Pathol 55, 187-193.

Dunwell, J. M. \& Gane, P. J. (1998). Microbial relatives of seed storage proteins: conservation of motifs in a functionally diverse superfamily of enzymes. J Mol Evol 46, 147-154.

Dunwell, J. M., Khuri, S. \& Gane, P. J. (2000). Microbial relatives of the seed storage proteins of higher plants: conservation of structure, and diversification of function during evolution of the cupin superfamily. Microbiol Mol Biol Rev 64, 153-179.

Dunwell, J. M., Purvis, A. \& Khuri, S. (2004). Cupins: the most functionally diverse protein superfamily? Phytochemistry 65, 7-17.

Dutton, M. V. \& Evans, C. S. (1996). Oxalate production by fungi: its role in pathogenicity and ecology in the soil environment. Can J Microbiol 42, 881-895.

Dutton, M. V., Evans, C. S., Atkey, P. T. \& Wood, D. A. (1993). Oxalate production by basidiomycetes, including the white-rot species
Coriolus versicolor and Phanerochaete chrysosporium. Appl Microbiol Biotechnol 39, 5-10.

Dutton, M. V., Kathiara, M., Gallagher, I. M. \& Evans, C. S. (1994). Purification and characterization of oxalate decarboxylase from Coriolus versicolor. FEMS Microbiol Lett 116, 321-326.

Emiliani, E. \& Bekes, P. (1964). Enzymatic oxalate decarboxylation in Aspergillus niger. Arch Biochem Biophys 105, 488-493.

Escutia, M. R., Bowater, L., Edwards, A., Bottrill, A. R., Burrell, M., Polanco, R., Vicuña, R. \& Bornemann, S. (2005). Cloning and sequencing of two Ceriporiopsis subvermispora bicupin oxalate oxidase allelic isoforms: implications for the reaction specificity of oxalate oxidases and decarboxylases. Appl Environ Microbiol 71, 3608-3616.

Espejo, E. \& Agosin, E. (1991). Production and degradation of oxalic acid by brown rot fungi. Appl Environ Microbiol 57, 1980-1986.

Fackler, K., Gradinger, C., Hinterstoisser, B., Messner, K. \& Schwanninger, M. (2006). Lignin degradation by white rot fungi on spruce wood shavings during short-time solid-state fermentations monitored by near infrared spectroscopy. Enzyme Microb Technol 39, 1476-1483.

Galkin, S., Vares, T., Kalsi, M. \& Hatakka, A. (1998). Production of organic acids by different white rot fungi as detected using capillary zone electrophoresis. Biotechnol Tech 12, 267-271.

Grujic, D., Salido, E. C., Shenoy, B. C., Langman, C. B., McGrath, M. E., Patel, R. J., Rashid, A., Mandapati, S., Jung, C. W. \& Margolin, A. L. (2009). Hyperoxaluria is reduced and nephrocalcinosis prevented with an oxalate-degrading enzyme in mice with hyperoxaluria. Am J Nephrol 29, 86-93.

Hakala, T. K., Maijala, P., Konn, J. \& Hatakka, A. (2004). Evaluation of novel wood-rotting polypores and corticioid fungi for the decay and biopulping of Norway spruce (Picea abies) wood. Enzyme Microb Technol 34, 255-263.

Hakala, T. K., Lundell, T., Galkin, S., Maijala, P., Kalkkinen, N. \& Hatakka, A. (2005). Manganese peroxidases, laccases and oxalic acid from the selective white-rot fungus Physisporinus rivulosus grown on spruce wood chips. Enzyme Microb Technol 36, 461-468.

Hammel, K. E. \& Cullen, D. (2008). Role of fungal peroxidases in biological ligninolysis. Curr Opin Plant Biol 11, 349-355.

Hatakka, A. (2001). Biodegradation of lignin. In Biopolymers, vol. 1: Lignin, Humic Substances and Coal, pp. 129-180. Edited by M. Hofrichter \& A. Steinbüchel. Weinheim, Germany: Wiley-VCH.

Hildén, K., Martinez, A. T., Hatakka, A. \& Lundell, T. (2005). The two manganese peroxidases $\mathrm{Pr}-\mathrm{MnP} 2$ and $\mathrm{Pr}-\mathrm{MnP} 3$ of Phlebia radiata, a lignin-degrading basidiomycete, are phylogenetically and structurally divergent. Fungal Genet Biol 42, 403-419.

Hofrichter, M., Vares, T., Kalsi, M., Galkin, S., Scheibner, K., Fritsche, W. \& Hatakka, A. (1999). Production of manganese peroxidase and organic acids and mineralization of ${ }^{14} \mathrm{C}$-labelled lignin $\left({ }^{14} \mathrm{C}\right.$-DHP $)$ during solid-state fermentation of wheat straw with the white rot fungus Nematoloma frowardii. Appl Environ Microbiol 65, 1864-1870.

Just, V. J., Stevenson, C. E. M., Bowater, L., Tanner, A., Lawson, D. M. \& Bornemann, S. (2004). A closed conformation of Bacillus subtilis oxalate decarboxylase OxdC provides evidence for the true identity of the active site. J Biol Chem 279, 19867-19874.

Just, V. J., Burrell, M. R., Bowater, L., McRobbie, I., Stevenson, C. E. M., Lawson, D. M. \& Bornemann, S. (2007). The identity of the active site of oxalate decarboxylase and the importance of the stability of active site lid conformations. Biochem J 407, 397-406.

Kathiara, M., Wood, D. A. \& Evans, C. S. (2000). Detection and partial characterization of oxalate decarboxylase from Agaricus biosporus. Mycol Res 104, 345-350. 
Kesarwani, M., Azam, M., Natarajan, K., Mehta, A. \& Datta, A. (2000). Oxalate decarboxylase from Collybia velutipes. Molecular cloning and its overexpression to confer resistance to fungal infection in transgenic tobacco and tomato. J Biol Chem 275, 7230-7238.

Khuri, S., Bakker, F. T. \& Dunwell, J. M. (2001). Phylogeny, function, and evolution of the cupins, a structurally conserved, functionally diverse superfamily of proteins. Mol Biol Evol 18, 593-605.

Kuan, I. C. \& Tien, M. (1993). Stimulation of Mn peroxidase activity: a possible role for oxalate in lignin biodegradation. Proc Natl Acad Sci U S A 90, 1242-1246.

Kupfer, D. M., Drabenstot, S. D., Buchanan, K. L., Lai, H., Zhu, H., Dyer, D. W., Roe, B. A. \& Murphy, J. W. (2004). Introns and splicing elements of five diverse fungi. Eukaryot Cell 3, 1088-1100.

Livak, K. J. \& Schmittgen, T. D. (2001). Analysis of relative gene expression data using real-time quantitative PCR and the $2^{-\Delta \Delta C_{\mathrm{T}}}$ method. Methods 25, 402-408.

Magro, P., Marciano, P. \& Di Lenna, P. (1988). Enzymatic oxalate decarboxylation in isolates of Sclerotinia sclerotiorum. FEMS Microbiol Lett 49, 49-52.

Mäkelä, M., Galkin, S., Hatakka, A. \& Lundell, T. (2002). Production of organic acids and oxalate decarboxylase in lignin-degrading white rot fungi. Enzyme Microb Technol 30, 542-549.

Mäkelä, M. R., Hildén, K. S., Hakala, T. K., Hatakka, A. \& Lundell, T. K. (2006). Expression and molecular properties of a new laccase of the white rot fungus Phlebia radiata grown on wood. Curr Genet 50, 323333.

Martinez, D., Challacombe, J., Morgenstern, I., Hibbett, D., Schmoll, M., Kubicek, C. P., Ferreira, P., Ruiz-Duenas, F. J., Martinez, A. T. \& other authors (2009). Genome, transcriptome, and secretome analysis of wood decay fungus Postia placenta supports unique mechanisms of lignocellulose conversion. Proc Natl Acad Sci U S A 106, 1954-1959.

Mehta, A. \& Datta, A. (1991). Oxalate decarboxylase from Collybia velutipes. Purification, characterization, and cDNA cloning. J Biol Chem 266, 23548-23553.

Micales, J. A. (1997). Localization and induction of oxalate decarboxylase in the brown-rot wood decay fungus Postia placenta. Int Biodeterior Biodegrad 39, 125-132.

Munir, E., Yoon, J.-J., Tokimatsu, T., Hattori, T. \& Shimada, M. (2001). New role for glyoxylate cycle enzymes in wood-rotting basidiomycetes in relation to biosynthesis of oxalic acid. J Wood Sci 47, 368-373.

Périé, F. H. \& Gold, M. H. (1991). Manganese regulation of manganese peroxidase expression and lignin degradation by the white rot fungus Dichomitus squalens. Appl Environ Microbiol 57, 2240-2245.

Périé, F. H., Reddy, V. B., Blackburn, N. J. \& Gold, M. H. (1998). Purification and characterization of laccases from the white-rot basidiomycete Dichomitus squalens. Arch Biochem Biophys 353, 349-355.
Reinhardt, L. A., Svedružić, D., Chang, C. H., Cleland, W. W. \& Richards, N. G. J. (2003). Heavy atom isotope effects on the reaction catalyzed by the oxalate decarboxylase from Bacillus subtilis. J Am Chem Soc 125, 1244-1252.

Rep, M., Duyvesteijn, R. G. E., Gale, L., Usgaard, T., Cornelissen, B. J. C., Ma, L.-J. \& Ward, T. J. (2006). The presence of GC-AG introns in Neurospora crassa and other euascomycetes determined from analyses of complete genomes: implications for automated gene prediction. Genomics 87, 338-347.

Sato, S., Liu, F., Koc, H. \& Tien, M. (2007). Expression analysis of extracellular proteins from Phanerochaete chrysosporium grown on different liquid and solid substrates. Microbiology 153, 30233033.

Shimada, M., Akamatsu, Y., Tokimatsu, T., Mii, K. \& Hattori, T. (1997). Possible biochemical roles of oxalic acid as a low molecular weight compound involved in brown-rot and white-rot wood decays. J Biotechnol 53, 103-113.

Sjöde, A., Winestrand, S., Nilvebrant, N.-O. \& Jönsson, L. J. (2008). Enzyme-based control of oxalic acid in the pulp and paper industry. Enzyme Microb Technol 43, 78-83.

Svedružić, D., Jónsson, S., Toyota, C., Reinhardt, L., Ricagno, S., Lindqvist, Y. \& Richards, N. (2005). The enzymes of oxalate metabolism: unexpected structures and mechanisms. Arch Biochem Biophys 433, 176-192.

Svedružić, D., Liu, Y., Reinhardt, L. A., Wroclawska, E., Wallace Cleland, W. \& Richards, N. G. J. (2007). Investigating the roles of putative active site residues in the oxalate decarboxylase from Bacillus subtilis. Arch Biochem Biophys 464, 36-47.

Tamura, K., Dudley, J., Nei, M. \& Kumar, S. (2007). MEGA4: Molecular Evolutionary Genetics Analysis (MEGA) software version 4.0. Mol Biol Evol 24, 1596-1599.

Tanner, A. \& Bornemann, S. (2000). Bacillus subtilis YvrK is an acidinduced oxalate decarboxylase. J Bacteriol 182, 5271-5273.

Urzúa, U., Kersten, P. J. \& Vicuña, R. (1998). Manganese peroxidasedependent oxidation of glyoxylic acid synthetized by Ceriporiopsis subvermispora produces extracellular hydrogen peroxide. Appl Environ Microbiol 64, 68-73.

Watanabe, T., Hattori, T., Tengku, S. \& Shimada, M. (2005). Purification and characterization of NAD-dependent formate dehydrogenase from the white-rot fungus Ceriporiopsis subvermispora and a possible role of the enzyme in oxalate metabolism. Enzyme Microb Technol 37, 68-75.

Wu, Q. \& Krainer, A. R. (1999). AT-AC pre-mRNA splicing mechanisms and conservation of minor introns in voltage-gated ion channel genes. Mol Cell Biol 19, 3225-3236.

Edited by: M. Tien 